\title{
Environmental Bases on the Exploitation of Crude Oil in Mexico
}

\author{
Dinora Vázquez-Luna \\ Colegio de Postgraduados \\ México
}

\section{Introduction}

Oil is one of the most important energy resources for the global economy. Regarding this, Mexico has an economic dependency of the oil industry that has being going on for decades. Based on the current oil production, the proven and possible reserves might last for ten years; still, if we consider probable and possible oil reserves, Mexico could count with an oil production for more than 30 years. Under this consideration, Mexico requires state of the art technologies for exploring, exploiting and processing crude oil.

Nowadays the technological and industrial development has to be environmentally responsible in accordance with the global needs. That is why the creation of new technologies and resources exploitation must be based on a responsible energetic development. Regarding this matter, being environmental friendly is a main goal for the society (Rodríguez et al., 2009), and gets to our attention that Mexico -until the seventiesdid not apply any environmental criteria while exercising its oil activities (Ortínez et al., 2003). In consequence, oil production, leading, transportation, storage and processing had a negative impact on soils (Trujillo et al., 1995; Rivera-Cruz \& Trujillo-Narcía, 2004), waters (Adams et al., 1999), and ecosystems at the southeast of the country (Santos et al., 2011).

In Mexico there are environmental regulations about hydrocarbons pollution, although these bypass criteria about the hydrocarbons' chronic effects on the ecosystems. However, in accordance with the current development conditions, it is necessary to introduce the environmental basis for the oil exploitation, whose main goal is to analyze the effects of the traditional oil related activities. The aim is to lay down the foundations for the creation of new technologies that contribute to a responsible and affordable energetic development for the country.

\section{Environmental effects of the oil exploitation in Mexico}

The world's economic sustenance, as based on the oil industry, has originated serious environmental issues (Hall et al., 2003). In Mexico, the oil industry has worn down the Southeastern natural resources, thus altering properties of soils (Rivera-Cruz \& TrujilloNarcía, 2004), sub-soils (Iturbe et al., 2007) and water (Ortiz et al., 2005), as a consequence of problems related oil extraction, processing and transportation (George et al., 2011). 
Most soils affected by hydrocarbons are located in tropical zones with high rain precipitation, augmenting the pollutants' dispersion through mangroves or zones with deficient drainage (Gutiérrez \& Zavala, 2002; Rivera-Cruz \& Trujillo-Narcía, 2004; GarcíaLópez et al., 2006; Vega et al., 2009). Additionally, this situation gets worse due to the age of the oil facilities, their lack of maintenance, as well as clandestine oil valves that have caused chronic spills of already weathered oil (Rivera-Cruz et al., 2005) which contains compounds of high molecular weight, endangering the resource's sustainability. The affected states with the highest number of environmental emergencies occurred in Mexico are Veracruz, Campeche and Tabasco, representing 78.7\% of the events related to PEMEX activities mainly because of its deteriorated pipelines, clandestine oil valves, corrosion and mechanical impacts (PEMEX, 2003; Olivera-Villaseñor \& Rodríguez-Castellanos, 2005).

The water bodies and the coastal zone are also affected by wastes derived from oil exploring, offshore production, sea and submarine transportation, shipment and storage operations, accidents during operations such as submarine oil pipes cracks, tankers accidents, spill outs and explosions at oil rigs (García-Cuéllar et al., 2004; Mei \& Yin, 2009).

During the seventies, Mexico developed oil exploitation technology and intensified its crude oil production and transportation via underwater pipelines to cargo floating buoys to storage ports located at Tabasco, as well as the oil's transformation and refining at Coatzacoalcos, Veracruz, and Salina Cruz. As a consequence, this created industrial networks all over the country that raised pollution issues at coastal zones, thus impacting the ecosystems of the Gulf of Mexico and the Pacific southeast coast (Carbajal \& Chavira, 1985; Botello, 1996; González-Lozano et al., 2006; Salazar-Coria et al., 2007). Nevertheless, conscience was not made until the IXTOC-I accident regarding the potential risks of the industry's activities (Jernelöv, 2010). Currently the main oil and gas production zone is located at the Gulf of Mexico, in the Campeche maritime zone where there are severely affected ecosystems after more than three decades of oil exploitation (García-Cuéllar et al., 2004). The last Gulf of Mexico disaster was estimated three times that of the Valdez spill (Trevors \& Saier, 2010).

On the other hand, in Mexico was installed the first and largest oil refinery (until 2004) in Latin America, dating from 1908; the environmental deterioration is evident after more than one hundred years of oil exploitation. The effects are observed at the lower Coatzacoalcos River (Toledo, 1995; González-Mille et al., 2010) as it has suffered the impacts of the oil refining and transportation processes since the swamp areas surrounding the oil refinery are used as waste traps. In addition, accidents related to carelessness during the load and cleaning of the tankers, as well as the discharge of the cooling water from the Minatitlán refinery into the river have created a complex mixture of hazardous materials that pollute the lower Coatzacoalcos River area directly, affecting both the fishing resources and the inhabitants (Toledo, 1983; Rosales-Hoz. \& Carranza-Edwards, 1998; Cruz-Orea et al, 2004; Ruelas-Inzunza et al, 2009; Ruelas-Inzunza et al., 2011).

Concurrently, we must add the petrochemical activity to the oil exploring and refining processes (Rao et al., 2007a). With the creation of petrochemical complexes since 1960, these activities increased the impact of the area conditioning where the industrial zones were located (Ortiz et al., 2005). Additionally, huge amounts of materials were dredged in order to build the artificial dock of Pajaritos. The industrial plants operation, the numerous 
transportation networks (petrochemical ducts and pipelines) and the linking earth systems built at the lower areas caused other activities with an environmental impact for the zone (Toledo, 1995; Adams et al., 2008). Another environmental effect of the intensity of the oil exploitation has been the loss of swamps, mangroves, and other elements of the water coastal systems that must be attended given its importance for the environmental services (Gutiérrez \& Zavala, 2002; Bahena-Manjarrez et al., 2002).

\section{Crude oil toxicity}

Toxicity is the ability of a chemical substance to damage and alter certain functions of the biological systems (Rivero et al., 2001). There are two toxicity criteria for the natural systems. Acute toxicity is produced by large, short-termed, accidental polluting agents' discharges (Roth \& Baltz, 2009), although it may have long term effects. On the other hand, chronic toxicity is expressed by effects noticed on the long term due to relatively small amounts of a toxic compound found on air, water or soil (Scarlett et al., 2007).

Crude oil is constituted by a complex hydrocarbon mixture and a wide range of n-alkanes $\left(\mathrm{C}_{6}-\mathrm{C}_{60}\right)$, alkenes, aromatic hydrocarbons, as well as polar fractions formed by asphaltene and resins (Salanitro et al., 2000). From these, hydrocarbons with of the highest molecular weight are the most persistent within the environment (Rivera-Cruz \& Trujillo-Narcía, 2004; Kostecki et al., 2005). The oil toxicity within the ecosystems depends on the physical and chemical characteristics of former's components (Vega et al., 2009), discharges time and types (Romaniuk et al., 2007), weathered degree (Rivera-Cruz et al., 2005), biological (RiveraCruz et al., 2002) and environmental (King et al., 2006) factors. In this sense, oil can affect the natural systems differentially.

In Mexico, the main oil pollution sources are the oil-well pits and the deficiencies in their maintenance, the discharges of the processing facilities, petrochemical plants and oil ducts cracks since most of the facilities are sixty years ago (Botello, 1990). There is a systemic and synergic interaction of the effects of the hydrocarbon polluted soils; in this sense, all of the ecosystems' components are altered, which affects the soils' properties, the present microorganisms, and even the plants' growth and reproduction, endangering the ecosystems' sustainability (Palma-López et al., 2007).

\subsection{Ground ecosystem: soil, microorganisms and plants}

The oil affectations are due mainly to oil spills; the negative effects of crude oil depend on the spill type (Kolesnikov et al., 2010), the zone's ecological characteristics, the amount and type of spilled oil, as well as the time over the soil (Hernández-Acosta et al., 2004) and weathered degree (Rivera-Cruz et al., 2005). In this sense, the pollution levels vary in accordance with the hydrocarbons' source, the age of the oil facilities and their deterioration (Adams et al., 1999). Hydrocarbon polluted soils also experience physical, chemical and biological processes (Li et al., 1997; Martínez \& López, 2001; Rivera-Cruz et al., 2002; RiveraCruz, 2004), altering the sustainability and productivity of the systems (FAO et al., 1980).

Nevertheless, there are properties inherent to soils that favor the fixation and toxicity of the pollutants (Charman \& Murphy, 2007). For instance, soils with a clay texture take a long time to recover from an oil spill, while the thick texture soils recover in short time 
(Hernández-Acosta et al., 2006). Still, this last texture can favor mobility towards the phreatic surfaces by the infiltration of the pollutant (Iturbe et al., 2007), thus widening the range of the hydrocarbon's toxicity (Srogi et al., 2007) towards the water tables (Fig. 1). Therefore, the aquatic organisms and the trophic chain can be severely affected, in consequence, the inhabitants consuming these products.

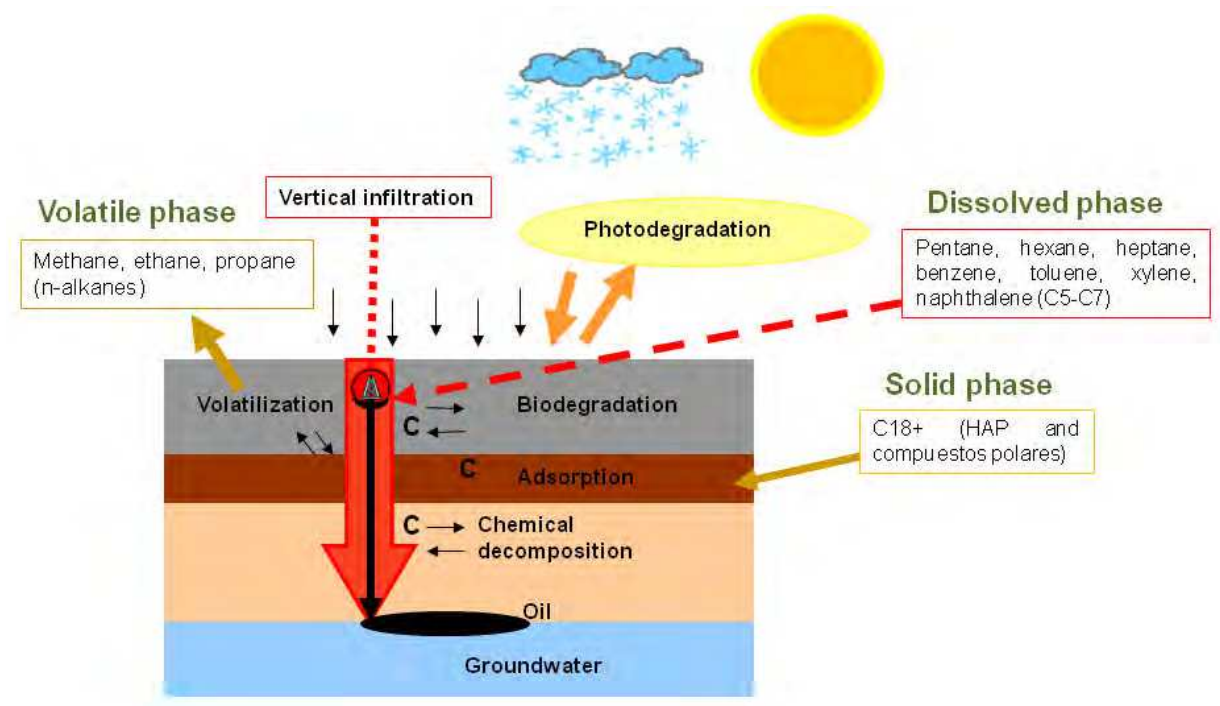

Fig. 1.Vertical infiltration process of crude oil (Eweis et al., 1998).

There are synergic effects due to the crude oil soil pollution, since the oil blocks the gas interchange with the atmosphere -given its anoxic properties- (Leitgi et al., 2008) and the change of the physical and chemical properties of the soils (Martínez \& López, 2001) severely diminish the microbial communities benefic to the soil (Labud et al., 2007). These microbiological variables are indeed a good indicator of the impact of a pollutant on the soil (Eibes et al., 2006).

The toxicity mechanisms caused by the oil on soils is not limited to the microorganisms, since it also includes plants that suffer from hydric stress (Chaîneau et al., 1997) due to the lack of water and nutrients. Concurrently, the lipid structures within the cells of the plants may be affected if the former are not quickly metabolized. In this sense, the oil has diverse effects over the plants since it inhibits the germination, growth and the biomass accumulation, reflecting these effects on a smaller plants production and, with time, in detriment of the natural resources sustainability.

The variables that have a determining effect over the plants affected by the soil hydrocarbons pollution are the soil ecology, the rhizosphere, emergence and germination, aerial and radical growth, biomass accumulation and salts present on the soil (Fig. 2). 

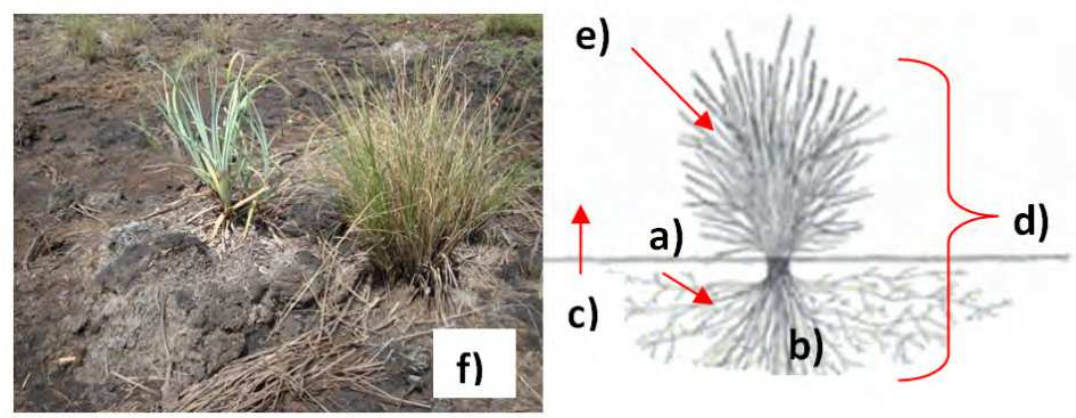

Fig. 2. Variables that have a determining effect over the plants affected by hydrocarbon polluted soils are: a) soil ecology, b) rhizosphere, c) emergence and germination, d) aerial and radical growth, e) biomass accumulation and f) salts presence.

a. Soil ecology: Oil also has an effect over the soil's biological composition (Tang et al., 2011), since toxic concentrations of oil on the soil inhibit the development of different species of nematodes, protozoa, rotifers, algae, fungi, bacteria and actinomycetes (Chaîneau et al., 2003; Ilarionov et al., 2003). Likewise, it induces the loss of biodiversity of microbial communities, which are of significant relevance in the biogeochemical cycles of the ecosystem affecting, as a consequence, its productivity (Rhodes \& Hendricks, 1990) and the nutrients availability.

b. Rhizosphere: It is the soil area surrounding the plant's root containing, 10 to 100 times more exudates than a soil lacking plants (Rao et al., 2007b). The root exudates (sugars, alcohols, and enzymes) provide enough carbon and energy for the rhizospheric microorganisms (Olguín et al., 2007; Muñoz et al., 2010) and it is precisely on this region where the intense and complex interactions between the roots systems, the microorganisms and the environment occur, with an increase of the total microbial activity (De la Garza et al., 2008). Oil blocks the gases interchange between the soil and the atmosphere, causing death or diminishment of the bacteria and nematodes (Tynybaeva et al., 2008). Nevertheless, Freedman (1989) and Germida et al. (2002) report some microorganisms can increase its population in the presence of hydrocarbons thanks to their capabilities for surviving under such conditions.

c. Emergence and germination: Oil forms a hydrophobic layer diminishing the hygroscopic water retention (Quiñones et al., 2003). This reduces the plants' water retention capability, directly affecting the seeds emergence and germination (VázquezLuna et al., 2010a). Other effect is reflected due to the volatile oil fractions that penetrate and damage the seeds embryo (Banks \& Schultz, 2005), diminishing its viability (Chaîneau et al., 1997) and affecting the ecosystem balance (Labud et al., 2007).

d. Aerial and radical growth. Recent researches find out that high hydrocarbons concentrations damage the plants growth and development since the pollutants diminish the radicle elongation and the vegetative growth (Vázquez-Luna et al., 2010a). García (2005) found a growth and dry weight reduction in rice seedlings after a 25 day exposure to $90,000 \mathrm{mg} \cdot \mathrm{kg}^{-1}$ of weathered oil. This effect could be attributed to the oil since it forms a hydrophobic layer, limiting the root's water and nutriments absorption. 
e. Biomass accumulation. When the plant grows and its needs increase, the lack of absorbed water diminishes the cellular swelling, reduces or inhibits the nutriments incorporation processes and affects the vegetative growth (Inckot et al., 2011), and the later grains or fruits harvest. On this regard, researches by Rivera-Cruz \& Trujillo Narcía (2004) found that the exposure to oil hydrocarbons concentrations of 2791, 9025 and $79,457 \mathrm{mg} \mathrm{kg}^{-1}$ on the soil inhibited the vegetative growth and reduced the plants biomass in the seedlings of Echinochloa polystachya, Brachiaria mutica and Cyperus spp grasses. The biomass reduction is due to the damage caused in the root system (Langer et al., 2010), making more difficult the plants' growth and, consequently, reducing their biomass (Zavala-Cruz et al., 2005) (Fig. 3). Additionally, there are visual reports of chlorosis and reddish hues characteristic of phenolic compounds on the leaves, due to the roots' stress and damages (Harvey et al., 2001; Peña-Castro et al., 2006) as shown on Figure 4.

f. Salts presence. Regarding salts presence, Adams et al. (2008) state that, when an oil spill occurs, high salinity is commonly associated to the production water or to the formation of the oil well. Soluble salts of calcium carbonates, nitrates and sulfates increase in presence of hydrocarbons (Ke et al., 2011), as shown on Figure 5.

a)

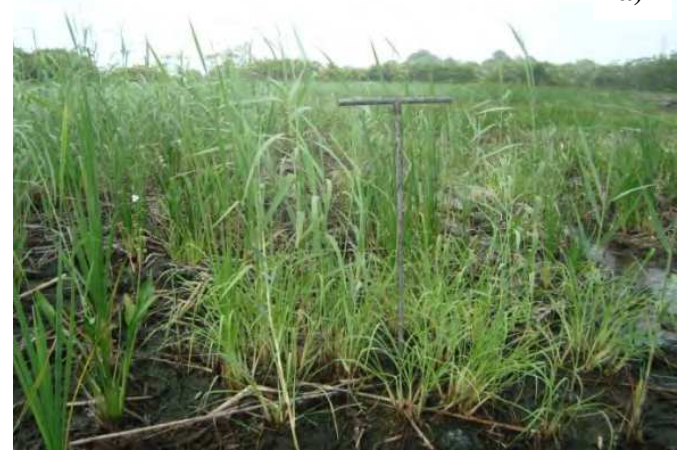

b)

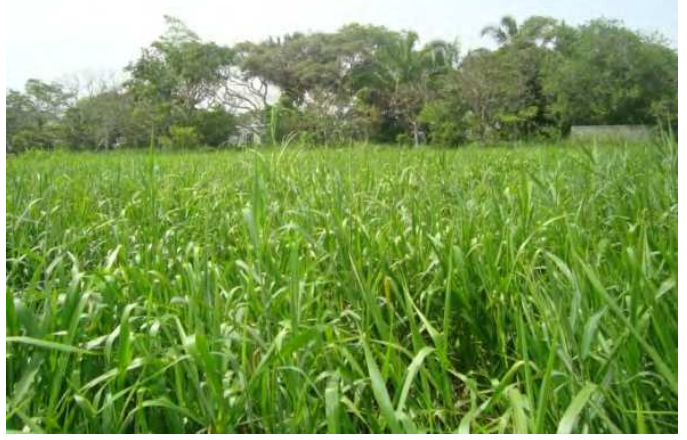

Fig. 3. Differences in grasses growth and biomass accumulation in a) polluted zone with $12,276 \mathrm{mg} \mathrm{kg}^{-1}$ of TPH and b) zone with $82 \mathrm{mg} \mathrm{kg}^{-1}$. 

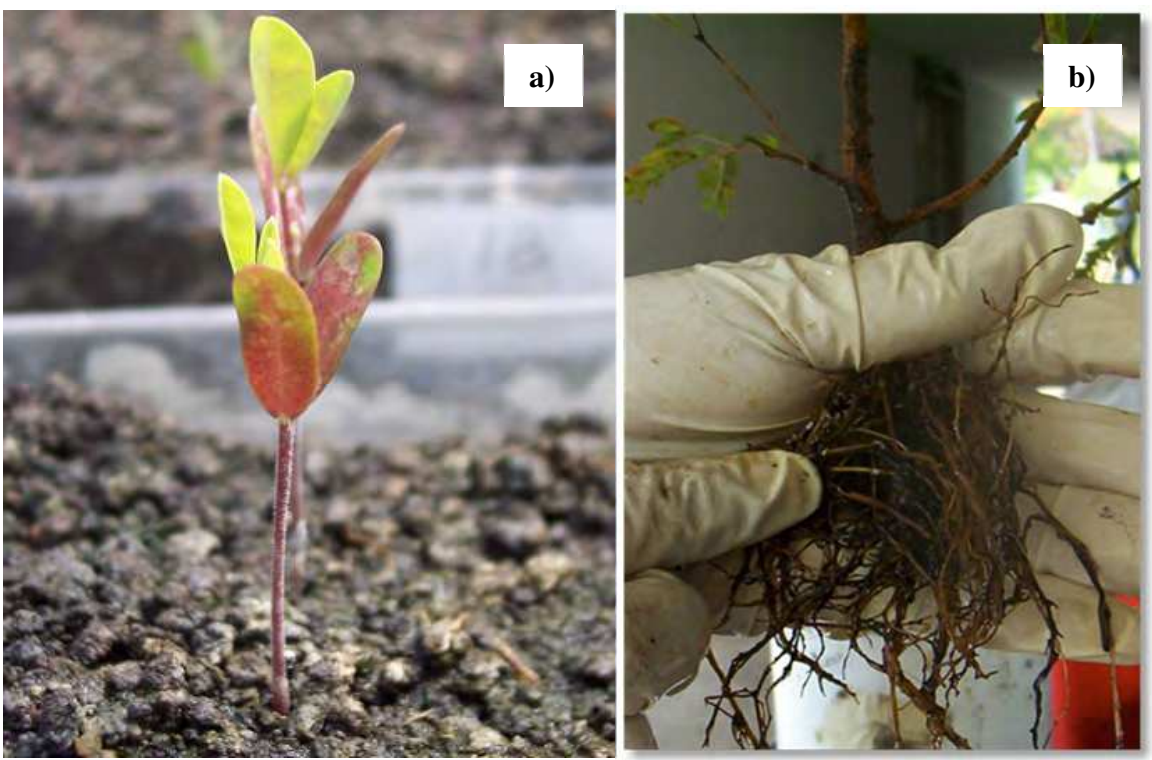

Fig. 4. Oil toxicity visible effects due to: a) chlorosis and reddish hues in cotyledons (Crotalia incana) and b) damages in Leucaena leucocephala roots exposed to $80,000 \mathrm{mg} \mathrm{kg}^{-1}$ of HTP.

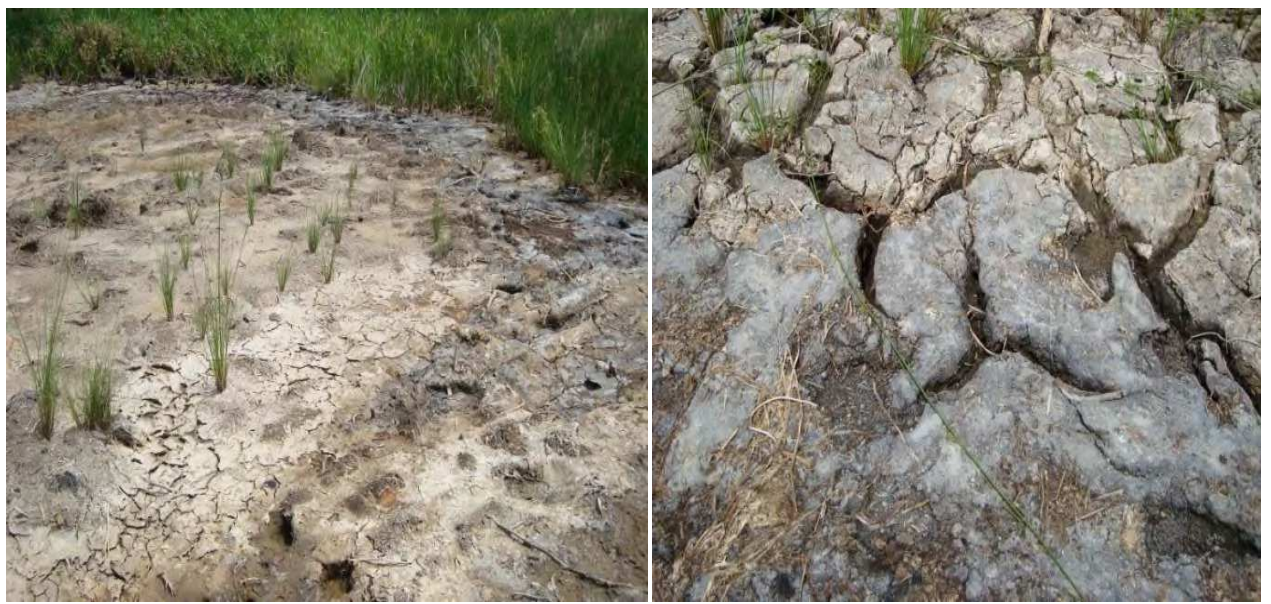

Fig. 5. Salts presence in polluted soils (with $12,276 \mathrm{mg} \cdot \mathrm{kg}^{-1}$ of HTP) as a collateral effect of the oil industry pollution.

\subsection{Marine ecosystems}

The oil toxicity in the marine environment is very complex due to the great diversity of factors intervening during an environmental risk event. When oil is spilled or introduced to the marine ecosystem (Mercer \& Trevors, 2011), it becomes weathered (Fig. 6), during which 
several processes take place, such as the evaporation of the volatile compounds, dispersion by means of waves, winds and turbulences (Chang et al., 2011), emulsification, which constitutes the main cause of the persistence of light and medium crude oils on the sea surface, dilution depending of the crude oil type, temperature, turbulence and dispersion, sedimentation or sinking of the particles by adhesion to the sediments or organic matter, and biodegradation (Botello, 1995; Nikolopoulou \& Kalogerakis, 2010; Prince, 2010). In Mexico, the Tonalá River in Veracruz and the Laguna de Términos in Campeche have shown the highest levels of dissolved hydrocarbons in the Gulf of Mexico (Botello et al., 1996).

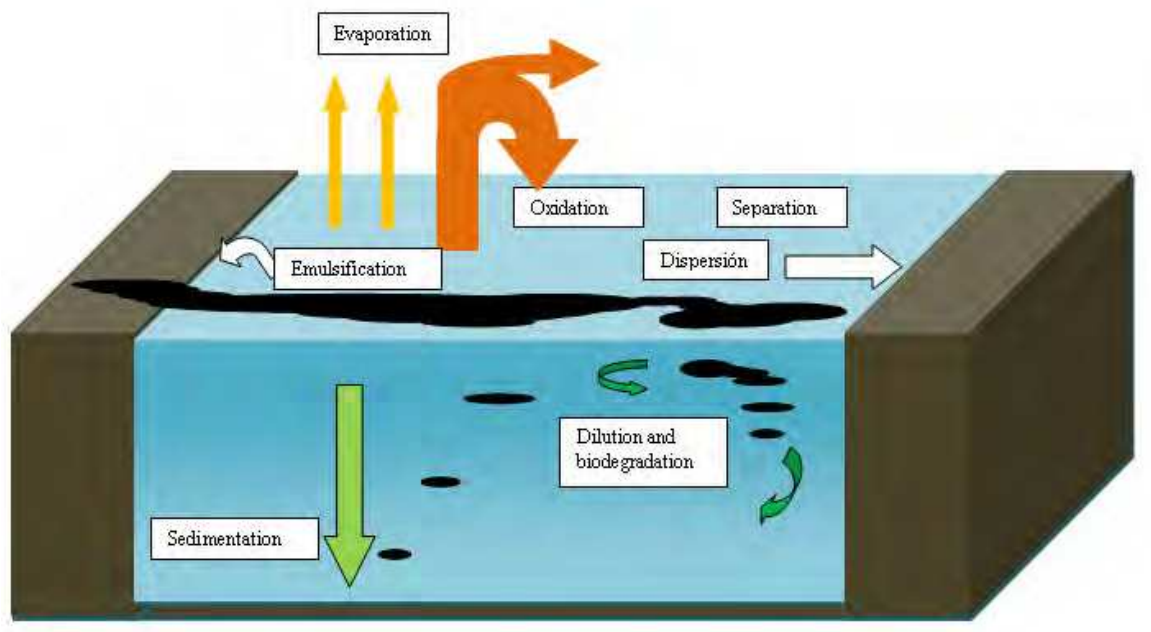

Fig. 6. Weathering process of the oil spilled in the sea, taken from Botello (1995).

Regarding the hydrocarbons assessment in the lower Coatzacoalcos River basin, the classical works of Botello \& Páez (1986) are outstanding since they found the highest polycyclic aromatic hydrocarbons (PAH) levels at the zones of fixed discharges or of intense oil activity (Garcia-Ruelas et al., 2004). Other studies determined the presence of PAH on 19 organic species such as fish, crustaceans and mollusks (sea bass, native sea bream, scallop and prawns) and the presence of benzo(a)pyrene and benzo(ghi)perylene, which are the most hazardous given its carcinogenic potential (Sharma et al., 2002). On the other hand, oil refinement and processing also contribute to broadening the range of toxicity caused to the fishing industry.

The marine oil pollution effects are harder to estimate (Trevors \& Saier, 2010), since there is no information previous to the beginning of the oil-industry activities over the effects on the ecosystems and its components; as a consequence, it is not possible to measure the magnitude of the oil industry in the marine seaway. Additionally, it has not been possible to determine the chronic effects of pollution over the ecosystems since the data available is very precise in a given time and determined concentrations (García-Cuéllar et al., 2004). Currently, there are studies proving the existence of considerable disturbances in the environment (Scarlett et al., 2007; Denoyelle et al., 2012); however, it is important to highlight 
that pollutants bioaccumulate in water organisms destined to human consumption (Webb, 2011).

\subsection{Human beings}

Mexico's oil industry history has been characterized by conflicts, power clashes, interests differences, competence between diverse companies, oilers and political leaders discrepancies, jealous preservation of the acquired rights by foreign interests, international consumer interest to have access a strategic product to a low cost, struggle for applying the 1917 Constitution over a given industry and the pressure from the workers to obtain a higher participation of the profit sharing (Brown, 2005).

The social conflicts attributed to the oil-zones development has been studied by different researchers; among them, Bustamante \& Jarrín (2005) point that the presence of oil-related activities does not improve the population life standard nor destroys it, although it must be said that such study did not consider the analysis of violence indicators nor the environment toxicity. On this regard, Avellaneda (2004) expresses that there cannot be an "environmental conflict" study which excludes the social dimension and vice versa, since the critics toward the oil-industry activities shall be discussed from several social, political, economic and cultural angles (Avellaneda, 2005). About this, a recent study by Vázquez et al. (2010b) found negative effects over the equitable development in areas near oil zones and considers the population health as a primordial entity for development. Regarding this, Elliot (1994) says that when the degree of residues generation exceeds the atmosphere, oceans, vegetation and soils natural capacity, these are absorbed affecting human health and the ecological systems.

A study made at the Ecuador's Amazonia found that women living near oil wells zones (up to $5 \mathrm{~km}$ ) presented symptoms such as tiredness, nasal and throat irritation, headache, eye irritation, earache, diarrhea and gastritis; these were associated with the proximity to oil wells and stations (San Sebastián et al., 2001). The main effects found in other studies regarding the acute exposure to oil after an oil spill at sea have been headache, throat and eyes irritation, tiredness, in addition to disorders such as anxiety and depression (Lyons et al., 1999). However, a repeated or long (chronic) exposure to low concentrations of oil volatile compounds can produce nausea, drowsiness, and headache (Kaplan et al., 1993). In accordance with Sánchez (2003), certain cases of pediatric intoxications are due to short chain hydrocarbons acting as asphyxiating agents given their high volatility and low viscosity, replacing the alveolar gas and producing hypoxia. When going through the alveolar membrane, they create symptoms such as the diminishment of the conscience threshold progressing towards convulsions, epileptic status or coma; additionally they induce the apparition of arrhythmias. On their side, the long chain hydrocarbons have a lower toxic power and large amounts are needed for them to produce central depression. The symptoms related range from symmetric sensorial dysfunction in the distal zones of the extremities, weakness of fingers and toes, loss of deep sensitive reflexes, to central nervous system depression, drowsiness and motor incoordination.

The hydrocarbons pollution might have teratogenic, mutagenic and carcinogen effects on human health (Neff, 2004). The oil hydrocarbons toxicology has been reviewed by the Agency for Toxic Substances and Diseases Registry (ATSDR) in the USA. According to this 
environmental agency, a major part of the total repercussion over the human health of all the chemical products on the soil is due to specific compounds called worrying chemical substances with a significant toxicological power. The worrying chemical products for gasoline, kerosene, and overall fuel polluted areas are benzene, toluene, ethilbenzene and xylene (BTEX) depending on the spill and the oilfield nature, which may contain heavy metals such as nickel and vanadium (López et al., 2008). Additional to the polycyclic (or polynuclear) aromatic hydrocarbons such as benzo(a)pyrene (EA, 2003), most of these hydrocarbons of high-molecular weight are present in soils with weathered oil or previous spills (Rivera-Cruz, 2004; Rivera-Cruz \& Trujillo-Narcía, 2004). About this, the International Agency for Research on Cancer (IARC), dependent of the World Health Organization (WHO), assessed benzo(a)anthracene, benzo(a)pyrene, and dibenz(a,h)anthracene as probable human carcinogens, and benzo(b)fluoranthene, benzo(k)fluoranthene, indene, pyrene, and naphthalene as possible human carcinogens (Kirkeleit et al., 2008).

Some compounds act as xenoestrogens, having the ability of stimulating the mammary gland tissue (De Celis et al., 2006); others may work as endocrine disruptors having effects on the reproduction (Chichizola, 2003). On this regard, cancer is the third cause of death on people aged 1 to 19 years; while only 5 to $10 \%$ of the malign tumors have been actually related to genetic causes; the rest might be influenced by a wide range of environmental factors (Anderson, 2001).

Because of this, it is important to regulate the oil refinement processes since they can pour into the atmosphere a large number of chemical compounds such as naphthalene, considered a dangerous airborne compound in accordance with the US Environmental Protection Agency (USEPA) since it can cause eye, skin and respiratory tract irritation. If inhaled for long periods it can damage the kidneys and the liver, in addition to skin allergies and dermatitis (Baars, 2002), cataracts, retina damage and also can attack the central nervous system. In high concentrations it can destroy red blood cells, causing hemolytic anemia (USEPA, 2003); as well, it is considered as a possible human carcinogen (Carmichael et al., 1991; ATSDR, 2004).

The main health risks are due to contact, inhalation and ingestion, and may increase depending on age, gender and exposure degree (Chen \& Liao, 2006). Some surveys show that among the 13 fractions of TPH, the aliphactics EC8-16 and aromatics EC10-21 are the main contributors to human health risks along all of the exposure routes (Park \& Park, 2010).

\section{The challenge: responsible energy development}

The Responsible Energy Development in Mexico is an immediate need in view of the holistic analysis of the effects of the oil industry over the natural resources (Patín, 2004). For a proposal to work, it is required the joint efforts of the scientific, technological, industrial, political, regulatory, legal and social sectors. In this sense, the environmental problems must be attacked from different angles, involving all of its elements (Fig. 7).

Mexico needs a holistic political view of the oil hydrocarbons pollution including the social, ecological and economical aspects, and -most of all- to create the conditions required for the Responsible Energy Development with an integral regulatory, economical and legislative frame. 


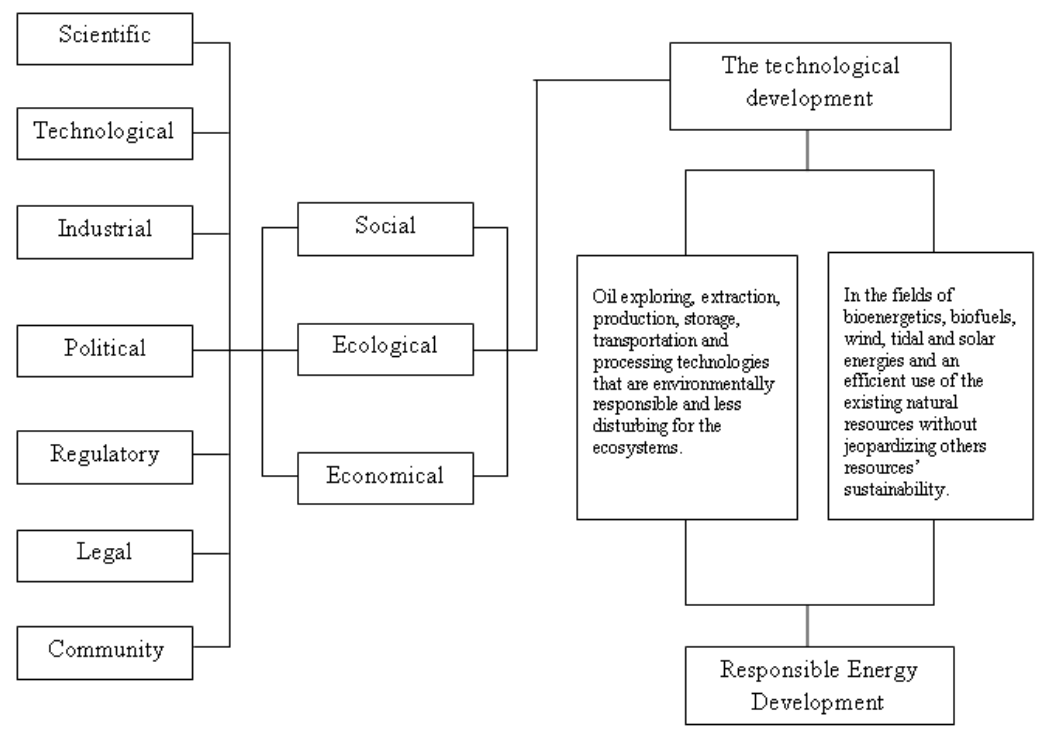

Fig. 7. Holistic approach in order to achieve a Responsible Energy Development.

On one hand, the oil spills and accidents that may occur due to maintenance deficiencies can be prevented with the proper maintenance and technological design on the side of the industry. On the other hand, citizens must avoid the clandestine oil valves and inform the authorities about fails; this information has been added into the environmental Mexican regulations. Nevertheless, there is still the need to increase the ecosystems protection due to the chronic effects of the polluting agents via strict legislation and regulations regarding the industrial wastes poured into the atmosphere, water bodies and soils, incorporating the periodic evaluation to the fishing resources for human consumption.

The economy is a subsystem within the whole development system and it is necessary that part of the oil surplus is used to finance research as well as for the technological development of adequate oil exploring, extraction, production, storage, transportation and processing technologies that are environmentally responsible and less disturbing for the ecosystems.

Finally, it is urgent to invest in the creation, research and development of new alternative energy sources for them to be gradually introduced within the country's energetic development. Such investments would enable the exploitation of profitable and sustainable energy sources, as well as the technological development in the fields of bioenergetics, biofuels, wind, tidal and solar energies and an efficient use of the existing natural resources without jeopardizing others resources' sustainability.

\section{Conclusion}

The environmental bases for the oil exploitation are the mainstays in order to analyze the effects of the traditional exploitation of oil in Mexico. The technological and scientific advances must be built over these bases, towards the development of new and better 
technologies for the resources exploitation. Consequently, this must cover the knowledge of the effects of pollution and thus promote the energetic sustainability without compromising human health, the environmental balance and the national economy.

Oil is fundamental for the economy of many countries. Therefore, it is not convenient to propose a radical change in the energetic system; rather, the proposal should consider the scientific and technological development based on two actions. The first one must focus on the exploring, extraction, processing, storage and transportation of crude oil with less risk and minimal disturbances of the natural resources. The second must bear in mind the gradual and integrated incorporation of the sustainable energies, allowing the efficient exploitation of resources without endangering others.

\section{Acknowledgment}

The author wants to especially thank Dr. Macario Vázquez Rivera and Irma Luna Capetillo for their valuable support and the Technical Council of COLPOS (Dr. Pilar Alberti Manzanares, Dr. Joel Zavala Cruz, Dr. Elizabeth Hernández Acosta, Dr. Miguel Escalona Maurice and Dr. Ruth De Celis Carrillo) for their scientific consultancy. Finally, the author wants to thank the "Fideicomiso Institucional 2010" of the Colegio de Postgraduados for financing the publication of the present article.

\section{References}

Adams, R. H.; Domínguez, V. I. \& García, L. (1999). Potencial de la biorremediación de suelo y agua impactados por petróleo en el trópico mexicano. Terra, 17 (2): 159-174

Adams, R. H.; Zavala-Cruz, J. \& Morales-García, F. (2008). Concentración residual de hidrocarburos en el suelo del trópico II: Afectación a la fertilidad y su recuperación. Interciencia, 33: 483-489

Anderson, R.N. (2001). Deaths: leading causes for 1999. Natl Vital Stat Rep, 49(11):1-87

ATSDR (Agency for Toxic Substances and Disease Registry). (2004). Public health statement for naphthalene, 1-methylnaphthalene,2-ethylnaphthalene. Available online at http://www.atsdr.cdc.gov/ToxProfiles/phs9018.html

Avellaneda, C. A. (2004). Petróleo, ambiente y conflicto en Colombia. In: Guerra, sociedad y medio ambiente. Martha Cárdenas Ed. Foro Nacional Ambiental. Bogotá, Colombia. $545 \mathrm{p}$.

Avellaneda, C. A. (2005). Petróleo, seguridad ambiental y explotación petrolera marina en Colombia. Revista de Ciencias Sociales, 21: 11-17

Baars, B-J. (2002). The wreckage of the oil tanker 'Erika' - human health risk assessment of beach cleaning, sunbathing and swimming. Toxicology Letters, 128(1-3): 55-68

Bahena-Manjarrez, J.; Rosales-Hoz L. \& Carranza-Edwards, A. (2002). Spatial and temporal variation of heavy metals in a tropical estuary. Environmental Geology, 42:575-582

Banks, M.K. \& Schultz, K.E. (2005). Comparison of plants for germination toxicity tests in petroleum-contaminated soils. Water, Air, E Soil Pollution, 167(1-4): 211-219

Brown, J. (2005). Los archivos del petróleo y la revolución mexicana. América Latina en la Historia Económica. Revista de Fuentes e Investigación, 23: 49-60

Botello, V. A. (1990). Impacto ambiental de los hidrocarburos organoclorados y microorganismos patógenos específicos en lagunas costeras del Golfo de México. Informe final 1989-1990, 
OEA-CONACYT. Inst. Cienc. Mar y Limnol., Univ. Nal. Autónoma de México. 69 p.

Botello, V. A. (1995). Fuentes, transformación y caracterización geoquímica del petróleo en el ambiente marino, p. 211-223. In: Golfo de México. Contaminación e impacto ambiental: diagnóstico y tendencias. Botello, V. A., J. L. Rojas G., J. A. Benítez y D. Zárate-Lomelí (Eds). EPOMEX. Serie Científica 5. Universidad Autónoma de Campeche. México $666 \mathrm{p}$.

Botello, V. A. (1996). Características, composición y propiedades fisicoquímicas del petróleo. In: Golfo de México. Contaminación e impacto ambiental: diagnóstico y tendencias. Botello, V. A., J. L. Rojas G., J. A. Benítez y D. Zárate-Lomelí (eds). EPOMEX. Serie Científica 5. Universidad Autónoma de Campeche. México 666 p.

Botello, V. A. \& Páez, F. (1986). La Contaminación: el problema crucial. Vol. I. Centro de Ecodesarrollo. México.140p.

Bustamante, T. \& Jarrín, M. C. (2005) Impactos sociales de la actividad petrolera en Ecuador: un análisis de los indicadores. Revista de Ciencias Sociales, 21: 19-34

Carbajal, P. J. L. \& Chavira, M. D. (1985). La contaminación de los sistemas lagunar-estuarios de las costas mexicanas. Elementos, 2(10): 58-64

Carmichael, P. L.; NíShé, M. \& Phillips, D. H. (1991) DNA adducts in human and mouse skin maintained in short-term culture and treated with petrol and diesel engine lubricating oils. Cancer Letters, 57(3): 229-235

Chaîneau, H. C.; Morel, J. L. \& Oudot, J. (1997) Phytotoxicity and uptake of fuel oil hydrocarbons. J. Environ. Qual. 26: 1478-1483

Chaîneau, C. H.; Yepremian, C.; Vidalie, J. F.; Ducreux, J. \& Ballerini, D. (2003). Bioremediation of a Crude Oil-Polluted Soil: Biodegradation, Leaching and Toxicity Assessments. Water, Air, and Soil Pollution, 144: 419-440

Chang, Y-L.; Oey, L-Y.; Xu, F-H.; Lu, H-F. \& Fujisaki, A. (2011). 2010 oil spill: trajectory projections based on ensemble drifter analyses. Ocean Dyn 61(6):829-839

Charman, P. E. V. \& Murphy, B. W. (2007). Soils their properties and management. Oxford University Press. Third edition. Hong Kong. 461 p.

Chen, S-C. \& Liao, C-M. (2006). Health risk assessment on human exposed to environmental polycyclic aromatic hydrocarbons pollution sources. Science of the Total Environment, 366: 112-123

Chichizola, C. (2003). Disruptores Endocrinos. Efectos en la Reproducción. Revista Argentina de Endocrinología y Metabolismo, 40(3): 172-188

Cruz-Orea, A.; Tomás, S.A.; Guerrero-Zuñiga, A. \& Rodríguez-Dorantes, A. (2004). Detection of an aromatic compound at the roots of Cyperus Hermaphroditus by photoacoustic techniques. International Journal of Thermophysics, 25(2): 603-610

Denoyelle, M.; Geslin, E.; Jorissen, F. J.; Cazes, L. \& Galgani, F. (2012). Innovative use of foraminifera in ecotoxicology: A marine chronic bioassay for testing potential toxicity of drilling muds. Ecological Indicators, 12: 17-25

De Celis, R.; Morgan, G.; Bravo A. \& Feria A. (2006). Cáncer de mama y exposición a hidrocarburos aromáticos. e-Gnosis, (4): 1-8

De la Garza, E. R.; Ortiz, Y. P.; Macias, B. A.; García, C. \& Coll, D. (2008). Actividad biótica del suelo y la contaminación por hidrocarburos. Revista Latinoamericana de Recursos Naturales, 4: 49-54.

EA (Environment Agency). (2003) Principles for Evaluating the Human Health Risks from Petroleum Hydrocarbons in Soils: A Consultation Paper. 43p. 
Eibes, G.; Cajthaml, T.; Moreira, M. T.; Feijoo, G. \& Lema, J. M. (2006). Enzymatic degradation of anthracene, dibenzothiophene and pyrene by manganese peroxidase in media containing acetone. Chemosphere, 64, 408-414

Elliot, A. J. (1994). An introduction to sustainable development. Zed Books. Londres. pp. 34-68

Eweis, J. B.; Ergas, S. J.; Chang, D. P. Y. \& Schroeder, E. D. (1998). Bioremediation principles. Series in Water Resources and Environmental Engineering. McGraw Hill. New York.

FAO, PNUMA \& UNESCO. (1980). Metodología provisional para la evaluación de la degradación de los suelos. Roma. $86 \mathrm{p}$.

Freedman, B. (1989). Environmental Ecology: the impacts of pollution and other stresses on ecosystem structure and function. Academic Press, Inc. San Diego California. USA. $424 \mathrm{p}$.

García, R. D. E. (2005). Estudio de la toxicidad de los petróleos nuevo e intemperizado en el cultivo de arroz (Oryza sativa L.). Tesis de Ingeniería Ambiental. División Académica de Ciencias Biológicas. Universidad Juárez Autónoma de Tabasco. Villaermosa, Tabasco. $87 \mathrm{p}$.

García-Cuellar, J. A.; Arreguín-Sánchez, F.; Vázquez, S. H. \& Lluch-Cota, D. B. (2004). Impacto ecológico de la industria petrolera en la sonda de Campeche, México, tras tres décadas de actividad: una revisión. Interciencia, 29: 311-319

García-López, E.; Zavala-Cruz, J. \& Palma-López, D. J. (2006). Caracterización de las comunidades vegetales en un área afectada por derrames de hidrocarburos. Terra Latinoamericana, 24: 17-26

Garcia-Ruelas, C., Botello, A.V., Ponce-Vélez, G. \& Díaz-González, G. (2004). Polycyclic aromatic hydrocarbons in coastal sediments from the subtropical Mexican Pacific. Marine Pollution Bulletin, 49: (5-6) 514-519

George, S.J.; Sherbone, J.; Hinz, C. \& Tibbett, M. (2011). Terrestrial exposure of oilfield flowline additives diminish soil structural stability and remediative microbial function. Environmental Pollution, 159: (10) 2740-2749

Germida, J. J.; Frick, C. M. \& Farrell, R. E. (2002). Phytoremediation of oil-contaminated soils. In: Developments in Soil Science, Volume 28B, A. Violante, P.M. Huang, J.-M. Bollag and L. Gianfreda (Eds). Elsevier Science B.V. 169-186

González-Lozano, M. C.; Méndez-Rodríguez, L. C.; López-Veneroni, D. G. \& VázquezBotello, A. (2006). Evaluación de la contaminación en sedimentos del área portuaria y zona costera de Salina Cruz, Oaxaca, México. Interciencia, 31(9): 647-656

González-Mille, D. J.; Ilizaliturri-Hernández, C. A.; Espinosa-Reyes, G.; Costilla-Salazar, R.; Díaz-Barriga, F.; Ize-Lema, I. \& Mejía-Saavedra, J. (2010). Exposure to persistent organic pollutants (POPs) and DNA damage as an indicator of environmental stress in fish of different feeding habits of Coatzacoalcos, Veracruz, Mexico. Ecotoxicology, 19:1238-1248

Gutiérrez, M. C. C. \& Zavala, C. J. (2002). Rasgos hidromórficos de suelos tropicales contaminados con hidrocarburos. Terra Latinoamericana, 20: 101-111

Hall, C.; Tharakan, P.; Hallock, J.; Cleveland, C. \& Jefferson, M. (2003). Hydrocarbons and the evolution of human culture. Nature, 426: 318-322

Harvey, P. J.; Campanella, B. F.; Castro, P. M. L.; Harms, H.; Lichtfouse, E.; Schaeffner, A. R.; Smrcek, S. \& Werck-Reichhart, D. (2001). Phytoremediation of polyaromatic hydrocarbons, anilines and phenols. Environmental Science Pollution Res., 9: 29-47 
Hernández-Acosta, E.; Rubiños-Panta, J. E. \& Albarado-López, J. (2004). Restauración de los suelos contaminados con hidrocarburos: Conceptos básicos. Colegio de Postgraduados. Montecillo, Estado de México. México. 148 p.

Hernández-Acosta, E.; Gutiérrez-Castorena, M. C.; Rubiños-Plata, J. E. \& Alvarado-López, J. (2006). Caracterización del suelo y plantas de un sitio contaminado con hidrocarburos. Terra Latinoamericana, 24: 463-470

Ilarionov, S. A.; Nazarov, A. V. \& Kalachnikova, I. G. (2003). The Role of Micromycetes in the Phytotoxicity of Crude Oil-Polluted Soils. Russian Journal of Ecology, 34(5):303308

Iturbe, R.; Flores, C.; Castro, A. \& Torres, L. G. (2007). Sub-soil contamination due to oil spills in six oil-pipeline pumping stations in northern Mexico. Chemosphere, 68: 893906.

Inckot., R. C.; Santos, G. de O.; De Souza, L. A. \& Bona, C. (2011) Germination and development of Mimosa pilulifera in petroleum-contaminated soil and bioremediated soil. Flora - Morphology, Distribution, Functional Ecology of Plants 206: (3) $261-266$

Jernelöv, A. (2010). The Threats from Oil Spills: Now, Then, and in the Future. Ambio, 39:353-366

Kaplan, M. B.; Brandt-Rauf, P.; Axley, J. W.; Shen, T. T. \& Sewell, G. H. (1993). Residential release of number 2 fuel oil: a contributor to indoor air pollution. Am J Public Health, 83(1): 84-88

Ke, L.; Zhang, C.; Guo, C.; Hui L. G. \& Fung Y. T. N. (2011). Effects of environmental stresses on the responses of mangrove plants to spent lubricating oil. Marine Pollution Bulletin, 63: (15-12) 385-395

Kirkeleit, J.; Riise, T.; Bråtveit, M. \& Moen, B. E. (2008). Increased risk of acute myelogenous leukemia and multiple myeloma in a historical cohort of upstream petroleum workers exposed to crude oil. Cancer Causes Control, 19:13-23

Kolesnikov, S. I.; Gaivoronskii, V. G.; Rotina, E. N.; Kazeev K. Sh. \& Val'kov, V. F. (2010). Assessment of soil tolerance toward contamination with black oil in the south of Russia on the basis of soil biological indices: A model experiment. Eurasian Soil Science, 43(8): 929-934

Kostecki, P.; Morrison, R. \& Dragun, J. (2005). Hydrocarbons. In: Encyclopedia of Soils in the Environment, Daniel Hillel (Ed.). Oxford. 217- 226 pp.

King, R. F.; Royle, A.; Putwain, P. D. \& Dickinson, N. M. (2006). Changing contaminant mobility in a dredged canal sediment during a three-year phytoremediation trial. Environmental Pollution, 143: 318-326

Labud, V.; Garcia, C. \& Hernández, T. (2007). Effect of hydrocarbon pollution on the microbial properties of a sandy and a clay soil. Chemosphere, 66: 1863-1871

Langer, I.; Syafruddin, S.; Steinkellner, S.; Puschenreiter, M. \& Wenzel, W. W. (2010). Plant growth and root morphology of Phaseolus vulgaris L. grown in a split-root system is affected by heterogeneity of crude oil pollution and mycorrhizal colonization. Plant Soil, 332:339-355

Leitgib, L.; Gruiz, K.; Fenyvesi, E.; Balogh, G. \& Murányi, A. (2008). Development of an innovative soil remediation: "Cyclodextrin-enhanced combined technology". Science of the Total Environmental, 392: 12-21

Li, X.; Feng, Y, \& Sawatsky N. (1997). Importance of soil-water relations in assessing the endpoint of bioremediated soils. Plant Soil, (192): 219-226 
López, E.; Schuhmacher, M. \& Domingo, J. L. (2008). Human health risks of petroleumcontaminated groundwater. Env Sci Pollut Res, 15 (3):278-288

Lyons, R. A.; Temple, M. F.; Evans, D., Fone, D. L. \& Palmer, S. R. (1999). Acute health effects of the sea empress oil spill. Journal Epidemiol Community Health, 53:306-310

Martínez, E. M. \& López, F. S. (2001). Efecto de hidrocarburos en las propiedades físicas y químicas de suelo arcilloso. Terra (19): 9-17

Muñoz, C. L. N.; Nevárez, M. G. V.; Ballinas, C. M. L. \& Peralta, P. M. R. (2010). Fitorremediación como una alternativa para el tratamiento de suelos contaminados. Revista Internacional de ciencia y Tecnología Biomédica, 3: 1-8

Mei, H. \& Yin, Y. (2009). Studies on marine oil spills and their ecological damage. J. Ocean Univ. China (Oceanic and Coastal Sea Research), 8(3): 312-316

Mercer, K. \& Trevors, J. T. (2011). Remediation of oil spills in temperate and tropical coastal marine environments. Environmentalist, 31:338-347

Neff, J. M. (2004). Bioaccumulation in marine organisms. Effect of contaminants from oil web produced water. Elsevier, Netherlands. pp. 241-313

Nikolopoulou, M. \& Kalogerakis, N. (2010). Biostimulation strategies for enhanced bioremediation of marine oil spills including chronic pollution. In: Handbook of Hydrocarbon and Lipid Microbiology, K. N. Timmis (Eds.), Springer-Verlag Berlin Heidelberg. 2522-2529

Olguín, E. J.; Hernández, M. E. \& Sánchez-Galván, G. (2007). Contaminación de manglares por hidrocarburos y estrategias de biorremediación, fitorremediación y restauración. Rev. Int. Contam. Ambient., 23: 139-154

Olivera-Villaseñor, R. E. \& Rodríguez-Castellanos, A. (2005). Estudio del riesgo en ductos de transporte de gasolinas y diesel en México. Científica, 9: (4) 159-165

Ortiz, P. M. A.; Siebe, C. \& Kram, S. (2005). Diferenciación ecogeográfica de Tabasco. Cap. 14. Pp. 305-322. In: Biodiversidad del estado de Tabasco. Bueno J., Álvarez F. y Santiago S. (Eds.) Instituto de Biología, UNAM-CONABIO. México, D. F.

Ortínez, B. O.; Ize, L. I. \& Gavilán, G. A. (2003). La restauración de los suelos contaminados con hidrocarburos en México. Instituto Nacional de Ecología. Gaceta ecológica, 69: 83-92

Quiñones, A. E. E.; Ferrera-Cerrato, R.; Gavi, R. F.; Fernández, L. L.; Rodríguez, V. R. \& Alarcón, A. (2003) Emergencia y crecimiento de maíz en un suelo contaminado con petróleo crudo. Agrociencia, 37: 585-594

Palma-López, D. J.; Cisneros, D. J.; Moreno, C. E. \& Rincón-Ramírez, J. A. (2007). Suelos de Tabasco: su uso y manejo sustentable. Instituto del Trópico Húmedo. Colegio de Postgraduados, Fundación Produce Tabasco A. C. Villahermosa, Tabasco. México. $195 \mathrm{p}$.

Park, I-S. \& Park, J-W. (2010). A novel total petroleum hydrocarbon fractionation strategy for human health risk assessment for petroleum hydrocarbon-contaminated site management. Journal of Hazardous Materials, 179(1-3): 1128-1135

Patín, S. A. (2004). Assessment of anthropogenic impact on marine ecosystems and biological resources in the process of oil and gas field development in the Shelf area. Water Resource, 31(4): 413-422

PEMEX (2003). Anuario estadístico. Exploración y producción. PEMEX. México. 64 pp.

Peña-Castro, J. M.; Barrera-Figueroa, B. E.; Fernández-Linares, L.; Ruiz-Medrano, R. \& Xoconostle-Cázares, B. (2006). Isolation and identification of up-regulated genes in bermudagrass roots (Cynodon dactylon L.) grown under petroleum hydrocarbon stress. Plant Science, 170: 724-731 
Prince, R. C. (2010). Bioremediation of marine oil spills. Handbook of Hydrocarbon and Lipid Microbiology, 24: 2617-2630

Rao, P. S.; Ansari, M. F.; Gavane, A. G.; Pandit, V. I.; Nema, P. \& Devotta, S. (2007a). Seasonal variation of toxic benzene emissions in petroleum refinery. Environ Monit Assess, 128:323-328

Rao, N. C. V.; Afzal, M.; Malallah, G.; Kurian, M. \& Gulshan, S. (2007b). Hydrocarbon uptake by roots of Vicia faba (Fabaceae). Environ Monit Assess, 132:439-443

Rhodes, A. N. \& Hendricks, C.W. (1990). A continuos-flow method for measuring effects of chemical on soil nitrification. Toxicity Assess, 5: 77-89

Rivera-Cruz, M. del C.; Ferrera-Cerrato, R.; Volke-Haller, V.; Fernández-Linares, L. \& Rodríguez-Vázquez, R. (2002). Poblaciones microbianas en perfiles de suelos afectados por hidrocarburos del petróleo en el estado de Tabasco, México. Agrociencia, 36: 149-160

Rivera-Cruz, M. del C. (2004). Clasificación de suelos tropicales influenciados por derrames de petróleo en Tabasco. Tecnociencia Universitaria, 7: 6-25

Rivera-Cruz, M. del C. \& Trujillo-Narcía, A. (2004). Estudio de toxicidad vegetal en suelos contaminados con petróleos nuevo e intemperizado. Interciencia, (29): 369-376

Rivera-Cruz, M. C.; Trujillo-Narcía, A.; Miranda, C. M. A. \& Maldonado, C. E. (2005). Evaluación toxicológica de suelos contaminados con petróleos nuevo e intemperizado mediante ensayos con leguminosas. Interciencia, 30: 326-331

Rivero, O.; Rizo, P.; Ponciano, G. \& Oláiz, G. (2001). Daños a la salud por plaguicidas. Introducción a la toxicología ambiental. Editorial. Manual Moderno. México. 488 p.

Rodríguez, S. M.; Pereira, M. E.; Ferreira, D. A.; Silva, E.; Hursthouse, A. S. \& Duarte, A. C. (2009). A review of regulatory decisions for environmental protection: Part I Challenges in the implementation of national soil policies. Environment International, 35: 202-213.

Romaniuk, R.; Brandt, J. F.; Ríos, P. R. \& Giuffré, L. (2007). Atenuación natural y remediación inducida en suelos contaminados con hidrocarburos. Ci. Suelo, 25: 139149

Rosales-Hoz, L. \& Carranza-Edwards, A. (1998). Heavy Metals in sediments from Coatzacoalcos river, Mexico. Bull. Environ. Contam. Toxicol, 60: 553-561

Roth, F. A-M. \&, Baltz, M. D. (2009). Short-Term Effects of an Oil Spill on Marsh-Edge Fishes and Decapod Crustaceans. Estuaries and Coasts, 32:565-572

Ruelas-Inzunza, J.; Páez-Osuna, F.; Zamora-Arellano, N.; Amezcua-Martínez, F. \& Bojórquez-Leyva, H. (2009). Mercury in biota and surficial sediments from Coatzacoalcos estuary, Gulf of Mexico: Distribution and seasonal variation. Water Air Soil Pollut, 197:165-174

Ruelas-Inzunza, J.; Páez-Osuna, F.; Ruiz-Fernández, A. C. \& Zamora-Arellano, N. (2011). Health risk associated to dietary intake of mercury in selected coastal areas of Mexico. Bull Environ Contam Toxicol, 86:180-188

Salazar-Coria, L.; Amezcua-Allieri, M. A.; Tenorio-Torres, M. \& González-Macías, C. (2007). Polyaromatic Hydrocarbons (PAHs) and metal evaluation After a diesel spill in Oaxaca, Mexico. Bull Environ Contam Toxicol, 79:462-467

Salanitro, J. P. (2000). Bioremediation of petroleum hydrocarbons in soil. Advances in Agronomy 72: 53-105

Sánchez, S., C.A. (2003). Intoxicación por hidrocarburos. In: Manual de intoxicaciones en Pediatría. Santiago Mintegui (eds). Ediciones Ergon. Majadahonda, Madrid. Capítulo 15. pp. 151-159 
San Sebastián, M.; Armstrong B. \& Stephens C. (2001). La salud de mujeres que viven cerca de pozos y estaciones de petróleo en la Amazonía ecuatoriana. Rev Panam Salud Publica, 9(6): 375-383

Santos, H. F.; Carmo, F. L.; Paes, J. E. S.; Rosado, A. S. \& Peixoto, R. S. (2011) Bioremediation of Mangroves Impacted by Petroleum. Water Air Soil Pollut 216:329-350

Scarlett, A.; Galloway, T. S. \& Rowland, S. J. (2007). Chronic toxicity of unresolved complex mixtures (UCM) of hydrocarbons in marine sediments. J Soils Sediments 7(4): 200206

Sharma, V. K.; Hicks, S. D.; Rivera, W. \& Vazquez, F. G. (2002). Characterization and degradation of petroleum hydrocarbons following an oil spill into a coastal environment of South Texas, U.S.A. Water, Air, and Soil Pollution, 134: 111-127

Srogi, K. (2007). Monitoring of environmental exposure to polycyclic aromatic hydrocarbons: a review. Environ Chem Lett, 5:169-195

Tang, J.; Wang, M.; Wang, F.; Sun, Q. \& Zhou, Q. (2011). Eco-toxicity of petroleum hydrocarbon contaminated soil. Journal of Environmental Sciences, 23(5): 845-851

Toledo, O. A. (1983). Como destruir el Paraíso. El Desastre Ecológico del Sureste. Centro de Ecodesarrollo-Océano, México. 149p.

Toledo, O. A. (1995). Economía de la Biodiversidad. PNUMA. Serie Textos Básicos. México. 273p.

Trevors, J. T. \& Saier, M. H. (2010). The legacy of oil spills. Water Air Soil Pollut 211:1-3

Trujillo, N. A.; Zavala, C. J. \& Lagunes, E. L. del C. (1995). Contaminación de suelos por metales pesados e hidrocarburos aromáticos en Tabasco. In: Memoria VII Reunión Científica-Tecnológica Forestal y Agropecuaria, INIFAP.Villahermosa, Tabasco, México. pp. 45-52

Tynybaeva, T. G.; Kostina, N. V.; Terekhov, A. M. \& Kurakov, A. V. (2008). The microbiological activity and toxicity of oil-polluted playa solonchaks and filled grounds within the Severnye Buzachi Oil Field (Kazakhstan). Eurasian Soil Science, 41(10): 1115-1123

USEPA. (2003). Health effects support document for naphthalene. EPA 822-R-03-005, Office of Water, Health and Ecological Criteria Division, Washington, DC. (Available online at http://www.epa.gov/safewater/ccl/pdf/naphthalene.pdf

Vázquez-Luna, D.; Castelán-Estrada, M.; Rivera-Cruz, M. C.; Ortiz-Ceballos, A. I. \& Izquierdo, R. F. (2010a). Crotalaria incana L. y Leucaena leucocephala Lam. (Leguminosae): Especies indicadoras de toxicidad por hidrocarburos del petróleo en suelo. Revista Internacional de Contaminación Ambiental 26: 183-191

Vázquez-Luna, D.; Manzanares, A. P.; Zavala, C. J; Hernández, A. E.; Escalona M. M. \& De Celis, C. R. (2010b). Impacto de la industria petrolera sobre el desarrollo equitativo en cuatro zonas de Huimanguillo, Tabasco. Naturaleza y Desarrollo, 8 (2): 6-22

Vega, A. F.; Covelo, F. E.; Reigosa, J. M. \& Andrade, M. L. (2009). Degradation of fuel oil in salt marsh soils affected by the Prestige oil spill. J. Hazard. Mater, 166: 1020-1029

Webb, J. (2011). Environmental contamination of fish and humans through deforestation and oil extraction in Andean Amazonia. Ph.D. diss., McGill University (Canada), In: Dissertations \& Theses: The Sciences and Engineering Collection [database on-line]; available from http://www.proquest.com (publication number AAT NR72714; accessed September 29, 2011).

Zavala-Cruz, J.; Gavi-Reyes, F.; Adams-Schroeder, R. H.; Ferrera-Cerrato, R.; Palma-López, D. J.; Vaquera-Huerta, H. \& Domínguez-Ezquivel, J. M. (2005). Derrames de petróleo en suelos y adaptación de pastos tropicales en el Activo Cinco Presidentes, Tabasco, México. Terra Latinoamericana, 23: 293-302. 


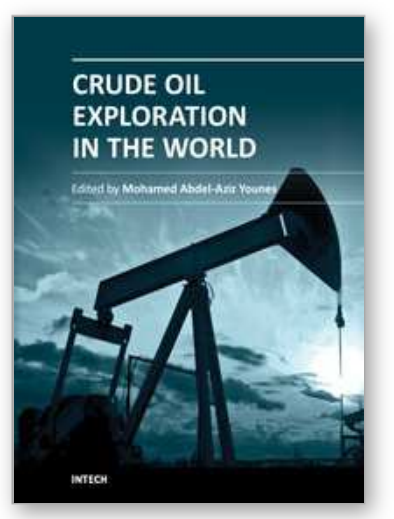

\section{Crude Oil Exploration in the World}

Edited by Prof. Mohamed Younes

ISBN 978-953-51-0379-0

Hard cover, 220 pages

Publisher InTech

Published online 16, March, 2012

Published in print edition March, 2012

"Crude Oil Exploration in the World" contains multidisciplinary chapters in the fields of prospection and exploration of crude oils all over the world in addition to environmental impact assessments, oil spills and marketing of crude oils.

\section{How to reference}

In order to correctly reference this scholarly work, feel free to copy and paste the following:

Dinora Vázquez-Luna (2012). Environmental Bases on the Exploitation of Crude Oil in Mexico, Crude Oil Exploration in the World, Prof. Mohamed Younes (Ed.), ISBN: 978-953-51-0379-0, InTech, Available from: http://www.intechopen.com/books/crude-oil-exploration-in-the-world/environmental-bases-on-the-exploitationof-crude-oil-in-mexico

\section{INTECH}

open science | open minds

\section{InTech Europe}

University Campus STeP Ri

Slavka Krautzeka 83/A

51000 Rijeka, Croatia

Phone: +385 (51) 770447

Fax: +385 (51) 686166

www.intechopen.com

\section{InTech China}

Unit 405, Office Block, Hotel Equatorial Shanghai

No.65, Yan An Road (West), Shanghai, 200040, China

中国上海市延安西路65号上海国际贵都大饭店办公楼405单元

Phone: +86-21-62489820

Fax: $+86-21-62489821$ 
(C) 2012 The Author(s). Licensee IntechOpen. This is an open access article distributed under the terms of the Creative Commons Attribution 3.0 License, which permits unrestricted use, distribution, and reproduction in any medium, provided the original work is properly cited. 